\section{Rheological behaviour modelling of cement paste with nanotubes and plasticizer}

\author{
GINTAUTAS SKRIPKIUNAS - Faculty of Civil Engineering, Vilnius Gediminas Technical University, \\ Lithuania gintautas.skripkiunas@vgtu.It \\ EKATERINA KARPOVA - Faculty of Civil Engineering, Vilnius Gediminas Technical University, \\ Lithuania - ekaterina.karpova@vgtu.It \\ Mindaugas DAUKSYS - Faculty of Civil Engineering and Architecture, Kaunas University of Technology, \\ Lithuania - mindaugas.dauksys@ktu.It
}

Érkezett: 2019. 11. 29. - Received: 29. 11. 2019. " https://doi.org/10.14382/epitoanyag-jsbcm.2019.32
Gintautas SKRIPKIUNAS

Is associate professor in the Vilnius Gediminas Technical University, Department of Building Materials and Fire Safety at VGTU, in Lithuania.

Ekaterina KARPOVA

Is graduated in the Izhevsk State Technical University (ISTU). At present she is a PhD student in the Vilnius Gediminas Technical University, at Department of Building Materials and Fire Safety, in Lithuania.

Mindaugas DAUKSYS Is professor in the Kaunas University of Technology and senior specialist in the Building Materials and Structures Research Centre, in Lithuania.

\begin{abstract}
Rheological properties of cement pastes determine the technological properties of concrete mixtures and have a significant influence on the concrete placement, including pumping, selfcompacting, 3D printing and others. The different types of additives and admixtures allow managing by the technological and rheological properties of cement systems. The lignosulphonate (LS), sulfonated naphthalene and melamine formaldehyde (NF), polycarboxylate ether (PCE) and acrylic polymer plasticizers, which change the consistency of concrete mixtures, are more widely used like plasticizing admixtures in construction practice nowadays. The carbon nanotubes are a perspective tool in managing by the rheological and technological properties of concrete in view of their outstanding mechanical, thermal, optical, electrical and some other properties.

The rheological behaviour of cement pastes with nanotubes and different types of polymer plasticizing admixtures was analyzed in the course of the current research using rotating rheometer with coaxial cylinders.

The cement pastes and concrete mixtures have the non-linear shear rate and shear stress dependence and require the application of non-linear rheological models such as Herschel-Bulkley or modified Bingham model. The approximation of experimental flow curves and evaluation of the rheological parameters such as yield stress, plastic viscosity and pseudoplastic indexes were performed based on the Herschel-Bulkley model in the course of the present research.

The testing of cement pastes in the presence of different plasticizing admixtures with and without MWCNT revealed the differences in rheological parameters depended on applied plasticizer. The molecular structure of plasticizing admixtures, small size, high aspect ratio and surface area of MWCNT, physical and chemical interactions between plasticizers and MWCNT can be a reason of observed changes in the rheological properties of cement pastes. The addition of MWCNT contributes to the obtaining of the cement paste of low dilatancy with definite flowability, yield stress and viscosity.
\end{abstract}

Keywords: cement paste, plasticizer, nanotubes, yield stress, viscosity, rheological model

Kulcsszavak: cementpép, folyósítószer, nanocsövek, folyáshatár, viszkozitás, reológiai modell

\section{Introduction}

The exploitation properties and durability of concrete structures depend on the properties of concrete mixtures and concrete placement technologies. Pumping of concrete mixtures is one the general way which is used for concrete transportation at the construction sites nowadays. The main rheological properties of concrete mixtures such as yield stress and plastic viscosity can be used for more accurate prediction of concrete mixtures behaviour in the course of a concreting. However, the evaluation of rheological parameters at the construction site is a challenging task caused by the complexity of rheological testing equipment. Therefore, the researchers are searching for a correlation between the main rheological parameters and technological properties of concrete mixtures [1-6]. For example, E. Secrieru et.al. investigated the effect of pumping on the rheological properties of fresh concrete. They performed a full-scale pumping experiment on a ready-mix concrete with the usage of viscometers for rheological test and revealed that pumping increases yield stress and reduces the viscosity of concrete mixture [1]. The research [2] reported the dependence between rheological parameters of concrete mixture and high pressure caused by concrete pumping.

In addition to pumping, the interest of researchers is devoted to the design of self-compacting concrete (SCC) [79] and development of 3D concrete printing technologies [10-12]. Based on the rheological parameters, the authors of the research [7] characterized the surface quality of SCC. They established that yield stress lower than $100 \mathrm{~Pa}$ and plastic viscosity lower than $10 \mathrm{~Pa} \cdot \mathrm{s}$ contribute to the surface defects of concrete caused by segregation. As for 3D printing technology, S.C. Paul et.al. studied 3D concrete printing technology and noticed that better pumpability of 3D printable cementitious materials is reached than thixotropy value is greater than $10000 \mathrm{~N} \mathrm{~mm} \mathrm{rpm} \mathrm{[10].}$

The fundamental rheological model, which is used for the description of the flow behaviour of cementitious systems, is the Bingham model. The significant amount of researches 
demonstrate the usage of this model for the explanation of the rheological behaviour of cement systems [13-15]. The Bingham model characterizes the linear dependence between shear stress $(\tau)$ and shear rate $(\gamma)$ of cement system and is described by the Equation (1):

$\tau=\tau_{0}+\mu_{p l} \cdot \gamma$

where: $\tau$ - shear stress, $\mathrm{Pa}$;

$\tau_{0}$ - yield stress of the cement paste, $\mathrm{Pa}$;

$\mu_{\mathrm{pl}}$ - plastic viscosity of the cement paste, $\mathrm{Pa} \cdot \mathrm{s}$;

$\gamma$ - shear rate, $\mathrm{s}^{-1}$.

The rheological behaviour of modern concrete modified by different types of additives and admixtures require an application of the non-linear rheological model. The number of research presents the non-linear character of flow behaviour for modified cement systems [16-23]. The Herschel-Bulkley model and modified Bingham model are used to characterize a non-linear flow behaviour of cement systems. They described by the Equations (2) and (3), respectively:

$\tau=\tau_{0}+K \cdot \gamma^{n}$

$\tau=\tau_{0}+\mu \cdot \gamma+c \cdot \gamma^{2}$

where: $\tau$ - shear stress, $\mathrm{Pa}$;

$\tau_{0}$ - yield stress of the cement paste, $\mathrm{Pa}$;

$K$ - consistency factor, $\mathrm{Pa} \cdot \mathrm{s}^{\mathrm{n}}$;

$\mu$ - plastic viscosity, Pa.s;

$\gamma$ - shear rate, $\mathrm{s}^{-1}$;

$\mathrm{n}$ - shear thinning/ thickening index $(\mathrm{n}<1 ; \mathrm{n}>1$,

respectively);

$c$ - second order term, Pa. $\mathrm{s}^{2}[16]$.

The usage of non-linear rheological model, such as HerschelBulkley rheological mode enable to derivate the pseudoplastic index of cement systems what is impossible in case of approximation according to the linear Bingham model. For example, A. Yahia tested the rheological behaviour of cement mortar with water-reducing admixtures and established the shear-thickening response of polycarboxylate plasticizer based on the Herschel-Bulkley model [21].

The increasing interest in the improvement of cement composites by addition of nano additives require an understanding of their action mechanism in the cement system. The analysis of rheological properties and their characterization by the rheological models is one of a way to describe the behaviour of nano additives in cement systems. As well as for the usage of chemical and mineral additives in cement paste, the rheological behaviour of nanomodified cement systems is described by non-linear rheological models. The research [23] presents the results of rheological testing of cement pastes modified by nano- $\mathrm{SiO}_{2}$, nano- $\mathrm{TiO}_{2}$, carbon nanotubes and nanofibers. The approximation of obtained rheological data was performed by a modified Bingham model.

The present research is focused on the analysis of the influence of different types of plasticizing admixtures (PL) and multi-walled carbon nanotubes (MWCNT) on the rheological behaviour of cement pastes. The rheological parameters were evaluated based on the Herschel-Bulkley model.

\section{Materials and testing methods}

\subsection{Materials}

The Portland cement without mineral additives CEM I 42.5

R conforming to EN 197-1 with water consumption of $26.6 \%$ and fineness by Blain of $3552 \mathrm{~cm}^{2} / \mathrm{g}$ was used as a binder.

The MWCNT suspension was prepared from the pellets "Graphistrength CW 2-45" produced by the company "Arkema" (France). The pellet contains 45wt. \% of MWCNT and 55 wt. $\%$ of carboxyl methyl cellulose (CMC). The MWCNT was characterized by the filament length of $0.1-10 \mu \mathrm{m}$ and the diameter of 15-20 nm. Distilled water was used as a dispersion medium for MWCNT. The lignosulphonate (LS), sulphonated naphthalene formaldehyde (NF) and polycarboxylate ether (PCE) plasticizers were applied in the research as a dispersant to distribute the MWCNT in the volume of water suspension and as a dispersing agent for cement pastes.

\subsection{Testing methods}

The ultrasonication by using a Bandelin Sonopuls HD 3400 ultrasonic homogenizer ( $400 \mathrm{~W}, 20 \mathrm{kHz}$ ) with probe VS 200 $\mathrm{T}$ (Ø25 mm, amplitude $-82 \mu \mathrm{m}$ ) for $6 \mathrm{~min}$ was applied to distribute the MWCNT in water. The more detailed description of a homogenization process of MWCNT suspension is presented in the research [14]. 4 types of MWCNT suspensions, including MWCNT suspension without PL and with LS, NF and PCE plasticizers, were obtained. The concentration of PL was of $3.8 \%$ in all aqueous MWCNT suspensions excluding MWCNT suspension without PL. The dosage of PL was chosen to reach the dosage of $1 \%$ bwoc in cement pastes as more widely used plasticizer dosage in cement systems.

The rheological test was carried out by rotational rheometer Rheotest RN 4.1 with coaxial cylinders (the scheme of cylinder measuring system is presented in Fig. 1) according to the mode presented in Fig. 2 at 5, 60, 120 min after cement paste mixing. $200 \mathrm{~g}$ of cement was used for preparing of cement paste for each rheological test. Water to cement ratio (W/C) was 0.30 and 0.25 for cement paste modified by MWCNT suspension without and with PL, respectively. The MWCNT suspensions were used as mixing water for the cement paste modification in the course of the rheological test. MWCNT dosage was of $0.06 \%$ bwoc in the course of rheological tests.

The main rheological parameters, such as yield stress $\left(\tau_{0}\right)$ and plastic viscosity $(\mu)$ were determined in the course of approximation of flow curve (dependence between shear stress $(\tau)$ and shear rate $(\gamma)$ in the range from 0.1 to $100 \mathrm{~s}^{-1}$ based on Herschel-Bulkley model. 


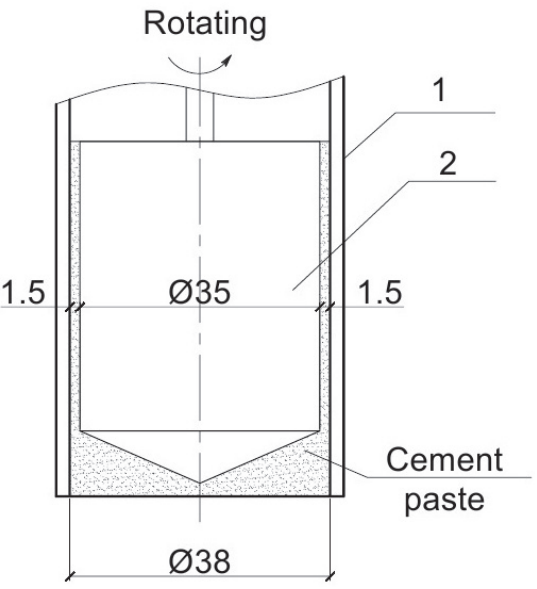

Fig. 1 Scheme of cylinder measuring system Rheotest RN 4.1

1. ábra A Rheotest RN 4.1. mérö rendszer vázlata

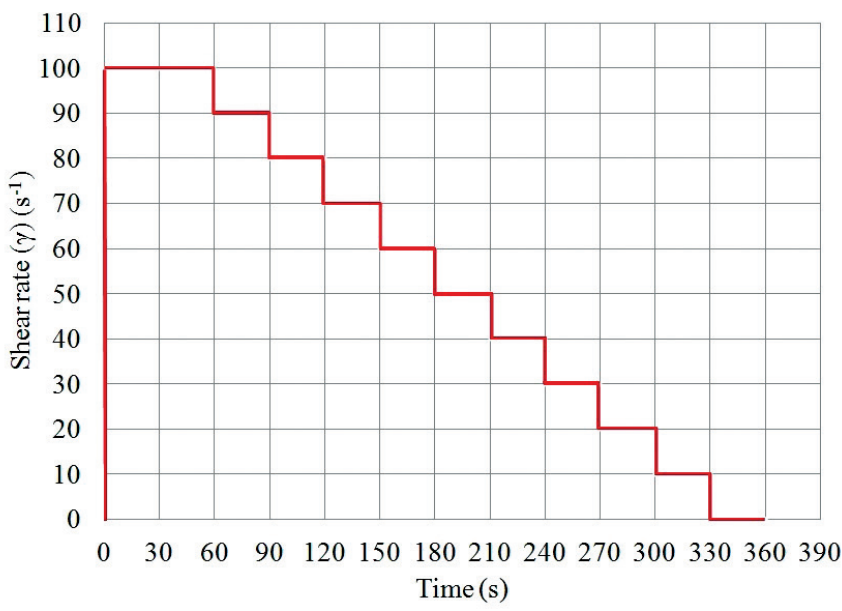

Fig. 2 Shear rate mode of the rheological test

2. ábra A reológiai teszt a nyírási sebesség meghatározásához

\section{Results of Investigation}

3.1 Influence of chemical admixtures on the flow behaviour of cement paste

The modification of cement paste by PL of different chemical structure leads to the changes in their rheological parameters in different ways. Fig. 3 represents the flow behaviour of cement pastes without and with the addition of LS, NF and PCE plasticizers in $5 \mathrm{~min}$ after cement paste mixing. The approximation of the obtained rheological curves was performed according to the Herschel-Bulkley model. The established rheological parameters, such as plastic viscosity, yield stress and shear thinning/thickening indexes identified the dependence between flow behaviour of cement pastes and applied type of PL. The rheological parameters obtained in the course of the approximation of flow curves by HerschelBulkley are listed in Table 1.

The significant decrease of yield stress value up to $0.3 \mathrm{~Pa}$ was reached in case of application of PCE plasticizer in the cement paste. The yield stress for LS and NF plasticizers were 11.4 and $5.2 \mathrm{~Pa}$, respectively.

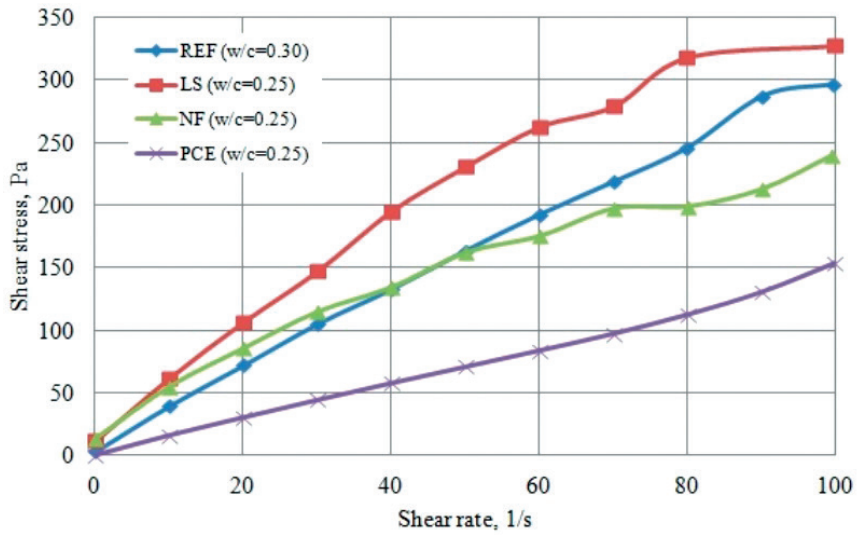

Fig. 3 Flow curves of cement pastes with different PL in 5 min after cement paste mixing

3. ábra Különböző PL tartalmú cementpépek folyási görbéi 5 perc alatt a cementpép keverése után

\begin{tabular}{lcccc} 
Specimen & W/C ratio & $\boldsymbol{\tau}_{0}, \mathrm{~Pa}$ & $\boldsymbol{\mu}, \mathrm{Pa} \cdot \mathbf{s}$ & $\mathbf{n}$ \\
Reference & 0.30 & 3.6 & 4.0 & 0.9 \\
\hline LS & 0.25 & 11.4 & 13.5 & 0.7 \\
\hline NF & 0.25 & 5.2 & 6.0 & 0.8 \\
\hline PCE & 0.25 & 0.3 & 0.6 & 1.2
\end{tabular}

Table 1 Rheological parameters of cement paste with different plasticizing admixtures obtained based on the Herschel-Bulkley model

1. táblázat A Herschel-Bulkley modell alapján kapott különböző folyósítószert tartalmazó cementpépek reológiai paraméterei

The plastic viscosity gained a smaller value for PCE plasticizer and was of $0.6 \mathrm{~Pa} \cdot \mathrm{s}$ in comparison with plastic viscosity of 13.5 and 6.0 Pa.s for LS and NF plasticizers, respectively.

Also, the difference in the rheological behaviour of the cement pastes with different PL was observed based on pseudoplastic indexes. The LS and NF plasticizers characterized by the indexes 0.7 and 0.8 , respectively, that identify their shear-thinning flow behaviour. The cement paste with PCE plasticizer demonstrated the shear thickening flow behaviour with the index of 1.2.

The $\mathrm{w} / \mathrm{c}$ ratio for the reference sample was of 0.30 caused by testing procedure. The values of the yield stress, plastic viscosity and pseudoplastic index were reached of 3.6 $\mathrm{Pa}, 4.0 \mathrm{~Pa} \cdot \mathrm{s}$ and 0.9 , respectively. Despite the differences in w/c ratio for the reference sample and samples with PL, it can be concluded that PCE plasticizer has greater plasticizing efficiency in cement paste in comparison with other PL. Mainly, the observed phenomenon can be explained by the differences in the molecular structure of polymers which causes the differences in their action mechanism in the cement systems.

\subsection{Influence of MWCNT with and without chemical admixtures on the flow behaviour of cement paste}

The present section shows the effect of MWCNT on the rheological behaviour of cement pastes. The separate and combine usage of MWCNT with PL were tested. The flow curves of cement pastes modified by MWCNT with and without PL are presented in Fig. 4-7. The values of yield stress, plastic viscosity and shear thinning/ thickening indexes are shown in 
Table 2. The values were obtained based on their approximation according to the Herschel-Bulkley rheological model.

Fig. 4 presents the flow curves for cement paste without and with MWCNT prepared in the same w/c ratio of 0.30 . The addition of MWCNT to the cement paste leads to the slight increase of yield stress and plastic viscosity in comparison with the reference sample by 8 and $5 \%$, respectively. The shear thinning index was changed from 0.94 for reference to 0.98 for nanomodified cement paste.

The addition of various types of PL in combination with MWCNT had a different impact on the rheology of cement pastes.

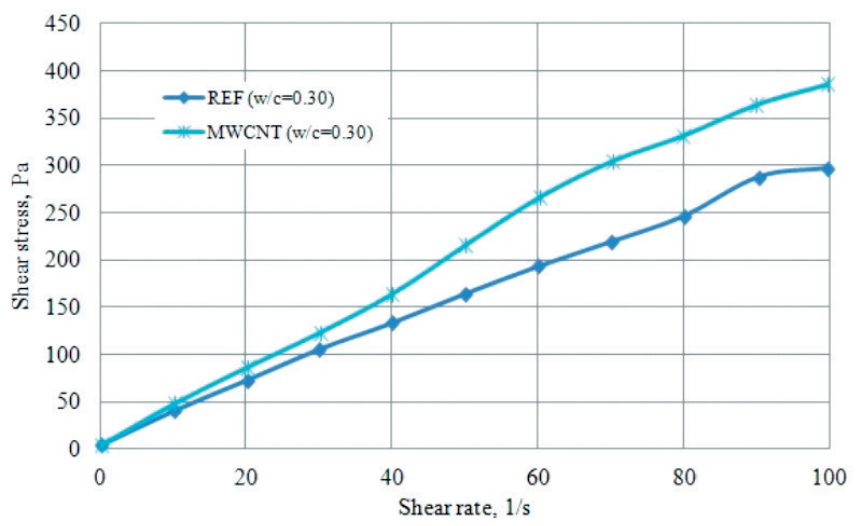

Fig. 4 Flow curves of cement paste with and without MWCNT in 5 min after cement paste mixing

4. ábra A cementpép folyási görbéi MWCNT-vel és anélkül 5 perc alatt a cementpép keverése után

Fig. 5 presents the results of rheological testing of cement pastes modified by MWCNT in the presence of LS plasticizer. The addition of MWCNT to cement paste with LS slightly increases the yield stress by $5 \%$ and not significantly decreases the plastic viscosity by $2 \%$. The modification of cement paste by MWCNT changes the shear thinning index from 0.70 to 0.64

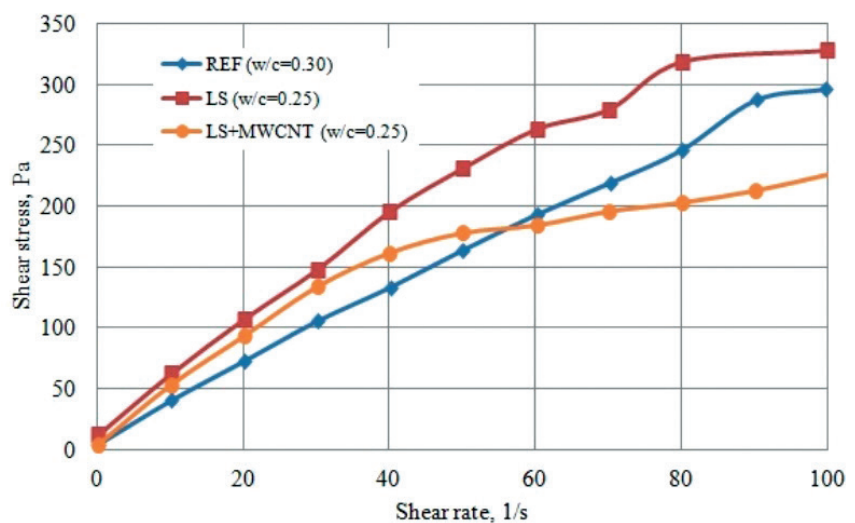

Fig. 5 Flow curves of cement paste with and without MWCNT in the presence of LS in 5 min after cement paste mixing

5. ábra A cementpép folyási görbéi MWCNT-vel és anélkül LS jelenlétében 5 perc alatt a cementpép keverése után
The cement paste modified by MWCNT in the presence of NF plasticizer characterized by the increase of yield stress and plastic viscosity by $4 \%$ and $20 \%$, respectively. The shear thinning was changed from 0.83 for cement paste modified by NF to 0.74 for cement paste with MWCNT and NF. The flow curves of cement pastes modified by MWCNT in the presence of NF are represented in Fig. 6.

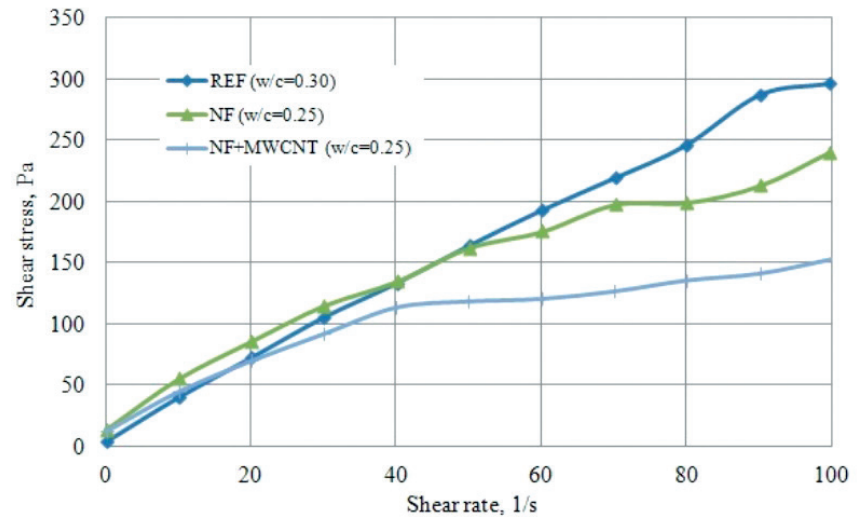

Fig. 6 Flow curves of cement paste with and without MWCNT in the presence of NF in 5 min after cement paste mixing

6. ábra A cementpép folyási görbéi MWCNT-vel és anélkül NF jelenlétében 5 perc alatt a cementpép keverése után

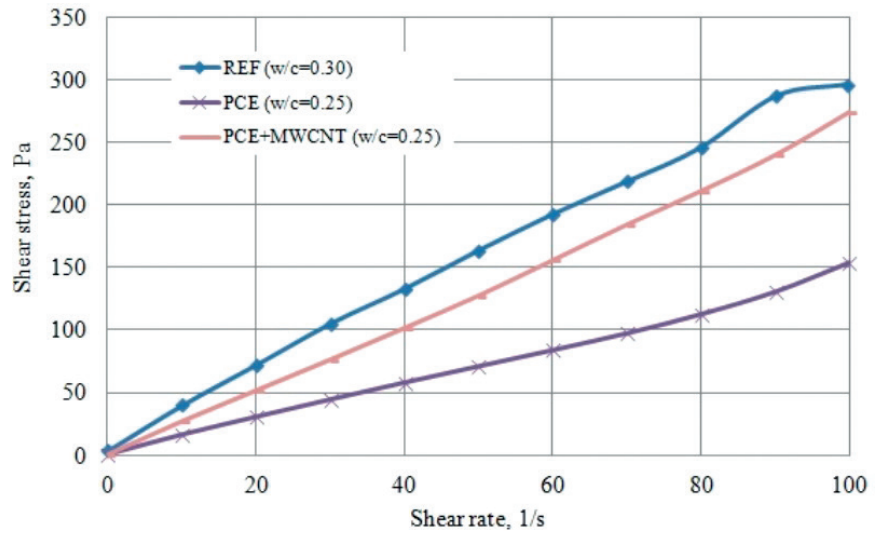

Fig. 7 Flow curves of cement paste with and without MWCNT in the presence of $P C E$ in 5 min after cement paste mixing

7. ábra A cementpép folyási görbéi MWCNT-vel és anélkül PCE jelenlétében 5 perc alatt a cementpép keverése után

The remarkable changes in rheological parameters of cement pastes were observed in case of their modification by MWCNT in the presence of PCE plasticizer. The flow curves of cement paste modified by MWCNT in the presence of PCE plasticizer are shown in Fig. 7. The addition of MWCNT to cement paste with PCE plasticizer led to the increase of the yield stress by $33 \%$ in comparison with cement paste modified only by PCE plasticizer. The plastic viscosity of nano modified cement paste increased in 2 times in comparison with cement paste with PCE plasticizer. The cement paste with PCE plasticizer characterized by shear thickening flow behaviour. The modification by MWCNT decreased the shear thickening index from 1.20 to 1.18 .

The absolute values of tested rheological parameters of cement paste with MWCNT in the presence of LS, NF and PCE plasticizers are given in Table 2. 


\begin{tabular}{lcccc} 
Specimen & W/C ratio & $\boldsymbol{\tau}_{\mathbf{0}}, \mathbf{P a}$ & $\mathbf{K}, \mathbf{P a} \cdot \mathbf{s}^{\mathbf{n}}$ & $\mathbf{n}$ \\
Reference & 0.30 & 3.6 & 4.0 & 0.94 \\
\hline MWCNT & 0.30 & 3.9 & 4.2 & 0.98 \\
\hline LS & 0.25 & 11.4 & 13.5 & 0.70 \\
\hline LS+MWCNT & 0.25 & 12.0 & 13.3 & 0.64 \\
\hline NF & 0.25 & 5.2 & 6.0 & 0.83 \\
\hline NF+ MWCNT & 0.25 & 5.4 & 4.8 & 0.74 \\
\hline PCE & 0.25 & 0.3 & 0.6 & 1.20 \\
\hline PCE+MWCNT & 0.25 & 0.4 & 1.2 & 1.18
\end{tabular}

Table 2 Rheological parameters of cement pastes with and without MWCNT in presence of plasticizing admixtures obtained based on Herschel-Bulkley model

2. táblázat A cementpépek reológiai paraméterei MWCNT-vel vagy anélkül folyósitószerek jelenlétében a Herschel-Bulkley modell alapján

MWCNT has an impact on the rheological properties of cement pastes. The small size, high aspect ratio, specific surface and porous structure of MWCNT can be a reason for the observed influence on the cement paste. These features of MWCNT contribute them to act physically and chemically in the cement paste. The usage of MWCNT in combination with various polymer PL can increase or decrease their impact on the rheological properties of the cement pastes in dependence on the chemical structure of PL and its ability to interact with MWCNT.

\section{Discussions of results}

As it was mentioned above, the Herschel-Bulkley and modified Bingham rheological models give more information about the rheological behaviour of the studied cement systems [16-23].

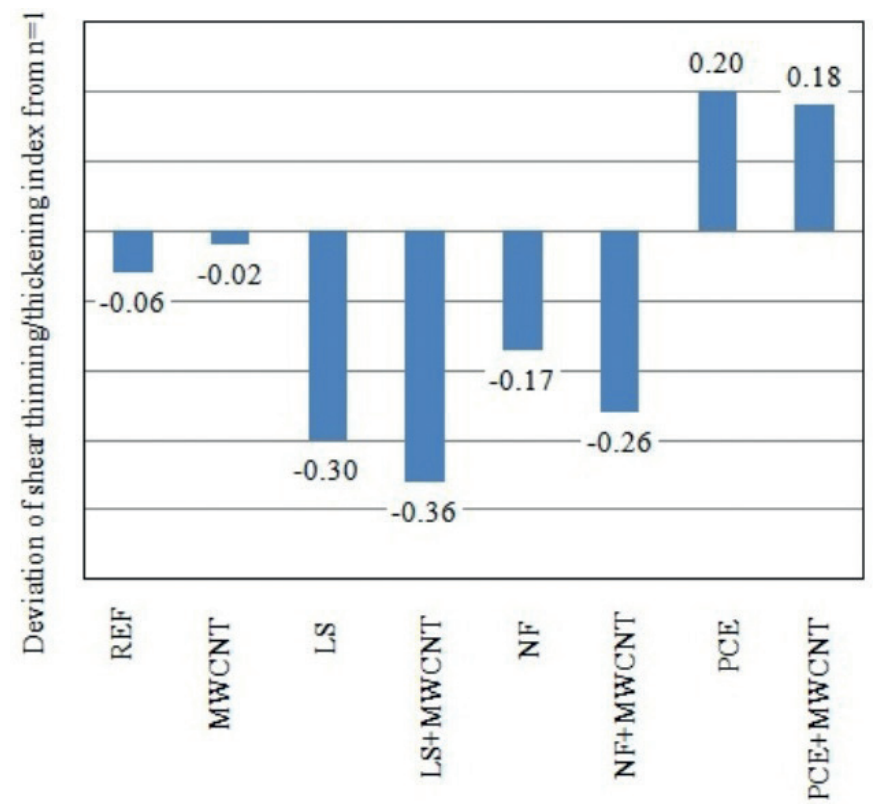

Fig. 8 Deviation of shear thinning/thickening indexes from $n=1$ in absolute units 8. ábra A nyírási vékonyodási / vastagodási indexek eltérése $n=1$-tól abszolút egységekben

In the course of the present research, the approximation of the rheological flow curves by Herschel Bulkley model identified the changes of shear thinning/thickening indexes

for cement pastes modified by MWCNT in the presence of PL. The shear thinning indexes for cement pastes with MWCNT in the presence of LS and NF were changed from 0.70 to 0.64 and from 0.83 to 0.74 , respectively. The cement pastes with MWCNT in the presence of PCE plasticizer were characterized by the changes of shear thickening index from 1.20 to 1.18 . The Fig. 8 presents the deviation of the pseudoplastic indexes of cement pastes from $\mathrm{n}=1$ in absolute units.

Based on the obtained results, it can be concluded that the addition of MWCNT to cement paste in the presence of various polymer PL leads to the decrease of dilatancy of cement paste. The level of changes in pseudoplastic index is depended on the type of applied PL and can be explained by its molecular structure.

\section{Conclusions}

1. The cement pastes have non-linear rheological behaviour. The processing of rheological data based on non-linear Herschel-Bulkley or Bingham rheological models allows obtaining more rheological parameters with high accuracy.

2. The various types of polymer plasticizing admixtures have a different influence on the cement paste flow behaviour. The application of LS, NF increases the thixotropy of cement pastes. The usage of PCE plasticizer revealed the increase of dilatancy of cement paste in comparison with the reference sample without admixtures.

3. The MWCNT have an impact on the rheological parameters of cement paste. The complex usage of MWCNT with LS and NF revealed the increase of yield stress by 5 and $4 \%$, respectively. The plastic viscosity decreased by $2 \%$ in case of a modification of cement paste by MWCNT and LS. The usage of MWCNT with NF plasticizer led to an increase of the plastic viscosity of the cement paste by $20 \%$. The more significant changes in rheological parameters of cement pastes were obtained for cement pastes modified by MWCNT in the presence of PCE plasticizer. The yield stress increased by $33 \%$ and plastic viscosity enhanced in 2 times in comparison with cement paste without MWCNT. The evaluation of shear thinning/ thickening indexes of nanomodified cement pastes identified that MWCNT contribute to the decrease of dilatancy of cement pastes. The observed differences in rheological behaviour of nanomodified cement paste in the presence of different plasticizing admixture can be explained by physical and chemical interactions between polymers and MWCNT.

4. Modification by MWCNT allows obtaining the cement paste of low dilatancy with definite flowability, yield stress and viscosity.

\section{References}

[1] Secrieru, E. - Cotardo, D. - Mechtcherine, V. - Lohaus, L. - Schrofl, C. - Begemann, C. (2018): Changes in concrete properties during pumping and formation of lubricating material under pressure. Cement and Concrete Research. Vol. 108, pp. 129-139,

https://doi.org/10.1016/j.cemconres.2018.03.018

[2] Kim, J. H. - Kwon, S. H. - Kawashima, S. - Yim, H. J. (2017): Rheology of cement paste under high pressure. Cement and Concrete Composites. Vol. 77, pp. 60-67, https://doi.org/10.1016/j.cemconcomp.2016.11.007

[3] Nerella, V.N. - Mechtcherine, V. (2018): Virtual Sliding Pipe Rheometer for estimating pumpability of concrete. Construction and Building Materials. Vol. 170, pp. 366-377, https://doi.org/10.1016/j.conbuildmat.2018.03.003 
[4] Xie, H. - Liu, F. - Fana, Y. - Yang, H. - Chen, J. - Zhang, J. - Zuo, C. (2013): Workability and proportion design of pumping concrete based on rheological parameters. Construction and Building Materials. Vol. 44, pp. 267-275, https://doi.org/10.1016/j.conbuildmat.2013.02.051

[5] Kim, J. S. - Kwon, S. H. - Jang, K. P. - Choi, M. S. (2018): Concrete pumping prediction considering different measurement of the rheological properties. Construction and Building Materials, Vol. 171, pp. 493-503, https://doi.org/10.1016/j.conbuildmat.2018.03.194

[6] Wallevik, J. E. - Wallevik, O. H. (2020): Concrete mixing truck as a rheometer. Cement and Concrete Research, Vol. 127, 105930 https://doi.org/10.1016/j.cemconres.2019.105930

[7] Megid, W. A. - Khayat, K. H. (2018): Effect of concrete rheological properties on quality of formed surfaces cast with self-consolidating concrete and superworkable concrete. Cement and Concrete Composites, Vol. 93, pp. 75-84, https://doi.org/10.1016/j.cemconcomp.2018.06.016

[8] Kostrzanowska-Siedlarz, A. - Jacek Gołaszewski, J. (2016): Rheological properties of High Performance Self-Compacting Concrete: Effects of composition and time. Construction and Building Materials, Vol. 115, pp. 705-715, https://doi.org/10.1016/j.conbuildmat.2016.04.027

[9] Iris, G.-T. - Belen, G.-F. - Fernando, M.-A. - Diego, C.-L. (2017): Selfcompacting recycled concrete: Relationships between empirical and rheological parameters and proposal of a workability box. Construction and Building Materials, Vol. 143, pp. 537-546,

https://doi.org/10.1016/j.conbuildmat.2017.03.156

[10] Paul, S. C. - Tay, Y. W. D. - Panda, B. - Tan M. J. (2018): Fresh and hardened properties of 3D printable cementitious materials for building and construction. Archives of Civil and Mechanical Engineering, Vol. 18, pp. 311-319, https://doi.org/10.1016/j.acme.2017.02.008

[11] Weng, Y. - Li, M. - Tan, M. J. - Qian, S. (2018): Design 3D printing cementitious materials via Fuller Thompson theory and Marson-Percy model. Construction and Building Materials, Vol. 163, pp. 600-610, https://doi.org/10.1016/j.conbuildmat.2017.12.112

[12] Lu, B. - Qian, Y. - Li, M. - Weng, Y. - Leong, K. F. - Tan, M. J. - Qian, S. (2019): Designing spray-based 3D printable cementitious materials with fly ash cenosphere and air entraining agent. Construction and Building Materials, Vol. 211, pp. 1073-1084,

https://doi.org/10.1016/j.conbuildmat.2019.03.186

[13] Gram, A. - Silfwerbrand, J. - Lagerblad, B. (2014): Obtaining rheological parameters from flow test - Analytical, computational and lab test approach. Cement and Concrete Research, Vol. 63, pp. 29-34, https://doi.org/10.1016/j.cemconres.2014.03.012

[14] Skripkiunas, G. - Karpova, E. - Barauskas, I. - Bendoraitiene, J. Yakovlev, G. (2018): Rheological Properties of Cement Pastes with Multiwalled Carbon Nanotubes. Advances in Materials Science and Engineering, Vol. 2018, Article ID 8963542, pp.1-13, https://doi.org/10.1155/2018/8963542
[15] Macijauskas, M. - Girskas, G. (2017): The Influence of Commonly Used Plasticizing Admixtures on the Plasticizing Effect of Cement Paste. Construction Science, Vol. 20, pp. 26-32, https://doi.org/10.2478/cons-2017-0004

[16] Feys, D. - Wallevik, J. E. - Yahia, A. - Khayat, K. H. - Wallevik, O. H. (2013): Extension of the Reiner-Riwlin equation to determine modified Bingham parameters measured in coaxial cylinders rheometers. Materials and Structures, Vol. 46, pp. 289-311,

https://link.springer.com/article/10.1617/s11527-012-9902-6

[17] Ma, S. - Qian, Y. - Kawashima, S. (2018): Experimental and modeling study on the non-linear structural build-up of fresh cement pastes incorporating viscosity modifying admixtures. Cement and Concrete Research, Vol. 108, pp. 1-9, https://doi.org/10.1016/j.cemconres.2018.02.022

[18] Guneyisi, E. - Gesoglu, M. - Algın, Z. - Yazıc1, H. (2016): Rheological and fresh properties of self-compacting concretes containing coarse and fine recycled concrete aggregates. Construction and Building Materials, Vol. 113, pp. 622-630, https://doi.org/10.1016/j.conbuildmat.2016.03.073

[19] Nguyen, V. H. - Remond, S. - Gallias, J. L. - Bigas, J. P. - Muller, P. (2006): Flow of Herschel-Bulkley fluids through the Marsh cone. J. NonNewtonian Fluid Mech., Vol. 139, pp. 128-134, https://doi.org/10.1016/j.jnnfm.2006.07.009

[20] Khayat, K. H. - Meng, W. - Vallurupalli, K. - Teng, L. (2019): Rheological properties of ultra-high-performance concrete - An overview. Cement and Concrete Research, Vol. 124, 105828, https://doi.org/10.1016/j.cemconres.2019.105828

[21] Yahia, A. (2011): Shear-thickening behavior of high-performance cement grouts - Influencing mix-design parameters. Cement and Concrete Research, Vol. 41, pp. 230-235,

https://doi.org/10.1016/j.cemconres.2010.11.004

[22] Reales, O. A. M. - Jaramillo, Y. P. A. - Botero, J. C. O. - Delgado, C. A. - Quintero, J. H. - Filho, R. D. T. (2018): Influence of MWCNT/ surfactant dispersions on the rheology of Portland cement pastes. Cement and Concrete Research, Vol. 107, pp. 101-109, https://doi.org/10.1016/j.cemconres.2018.02.020

[23] Jiang, S. - Shan, B. - Ouyang, J. - Zhang, W. - Yu, X. - Li, P. - Han, B. (2018): Rheological properties of cementitious composites with nano/ fiber fillers. Construction and Building Materials, Vol. 158, pp. 786-800, https://doi.org/10.1016/j.conbuildmat.2017.10.072

$\underline{\text { Ref.: }}$

Skripkiunas, G. - Karpova, E. - Dauksys, M.: Rheological behaviour modelling of cement paste with nanotubes and plasticizer Építőanyag - Journal of Silicate Based and Composite Materials, Vol. 71, No. 6 (2019), 184-189. p. https://doi.org/10.14382/epitoanyag-jsbcm.2019.32

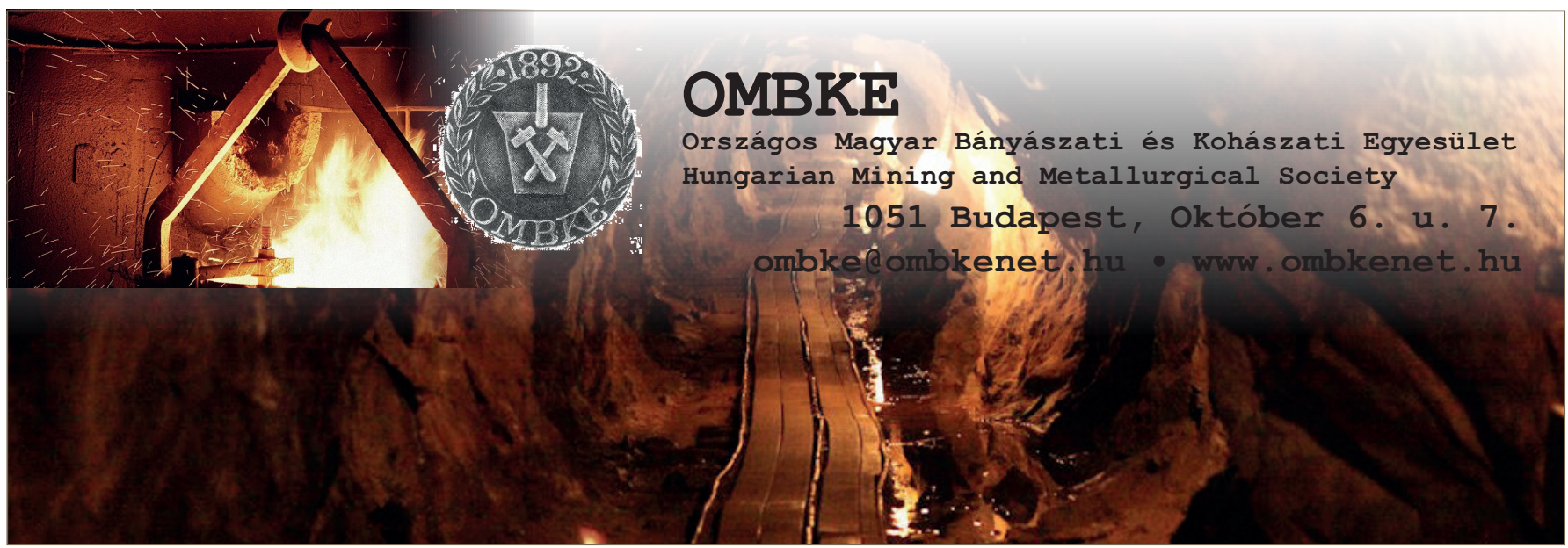

